\section{Effects of forest management on bird assem- blages in the Bialowieza Forest, Poland}

\author{
Dorota Czeszczewik ${ }^{(1)}$, Karol Zub $^{(2)}$, Tomasz Stanski ${ }^{(1)}$, \\ Mustapha Sahel $^{(3)}$, Anna Kapusta ${ }^{(1)}$, Wieslaw Walankiewicz ${ }^{(1)}$
}

\begin{abstract}
We examined the effects of different intensities of forest management practices on bird communities in the Bialowieza Forest, eastern Poland. Stands managed for more than 100 years (cutting, planting, removal of dead wood) and stands that were partially protected in nature reserves (sporadic sanitary cutting, removal of dead wood until 2008) were compared with unmanaged stands in the Bialowieza National Park by surveying the bird community during three breeding seasons (2010-2012). Surveys were conducted within three forest habitats: spruce-pine (Pino-Quercetum), lime-hornbeam (Tilio-Carpinetum) and ash-alder (Fraxino-Alnetum). Results showed that habitat structure significantly affected the avian community. The basal area of live trees had a positive effect on abundance of birds, while the density of live trees had negative significant effect on bird abundance and species diversity. We also found significantly lower abundance of insectivorous birds and cavity-nesters in managed compared with unmanaged stands. Birds' assembly in the spruce-pine and ash-alder stands were most sensitive to management. These results show that management can be used to sustain bird communities, including species of conservation concern.
\end{abstract}

Keywords: Bialowieza Forest, Breeding Bird Communities, Forest Biodiversity, Primeval Stands, Forest Management

\begin{abstract}
Introduction
Birds are often used as indicators of the quality of forest environments (Roberge \& Angelstam 2006, Gregory \& Van Strien 2010, Larsen et al. 2010). Forest management practices can affect the conservation value of forests for birds (Loehle et al. 2006 Hauer et al. 2010, Schwenk et al. 2012, Zhang \& Wang 2012). Forest bird species are particularly sensitive to habitat changes, especially habitat loss due to logging (Diaz et al. 2005, Tozer et al. 2010, Ghadiri Khanaposhtani et al. 2013), forest fragmentation (Piratelli et al. 2008), stand age and tree species composition (Thompson et al. 1999) and the amount of dead wood (Walankiewicz et al. 2002, 2011, Roberge et al. 2008, Tozer et al. 2010, Czeszczewik et al. 2013). Knowledge of how these forest elements affect bird assemblages is essential for avian
\end{abstract}

conservation (Diaz et al. 2005, Rosenvald et al. 2011, Ghadiri Khanaposhtani et al. 2013). These relationships have been studied extensively in the managed forests of Europe and North America (Keller et al. 2003, Roberge et al. 2008, Schlossberg \& King 2009, Rosenvald et al. 2011), but seldom managed forest stands have been compared with unmanaged, primeval forest to such purposes.

The Bialowieza Forest located in central Europe is one of the last remaining temperate lowland forests that has survived to the present in primeval condition (Tomialojć et al. 1984). By primeval forest we define a forest of great age without significant disturbance which exhibits unique ecological features. The best preserved stands are protected in the Bialowieza National Park (BNP), presenting a unique opportunity to study organisms under primeval conditions. How-

$\square$ (1) Department of Zoology, Siedlce University of Natural Sciences and Humanities, Prusa 12, 08-110 Siedlce (Poland); (2) Mammal Research Institute, Polish Academy of Sciences, 17230 Bialowieza (Poland); (3) ul. Lecha 7a/91, 05-400 Otwock (Poland)

@ Dorota Czeszczewik (dorota.czeszczewik@uph.edu.pl)

Received: Dec 23, 2013 - Accepted: Jul 24, 2014

Citation: Czeszczewik D, Zub K, Stanski T, Sahel M, Kapusta A, Walankiewicz W, 2015. Effects of forest management on bird assemblages in the Bialowieza Forest, Poland. iForest 8: 377-385 [online 2014-10-02] URL: http://www.sisef.it/iforest/contents/?id=ifor1212-007

Communicated by: Massimo Faccoli ever, for over a hundred years, a large part of the Bialowieza Forest, outside of the BNP, has been subjected to human activities including clear-cuts, selective cutting and tree planting (Bobiec 2002).

Since 1975 , the breeding bird communities of the BNP have been monitored in three forest types: spruce-pine (Pino-Quercetum), lime-hornbeam (Tilio-Carpinetum) and ashalder (Fraxino-Alnetum - Tomialojć et al. 1984, Tomialojć \& Wesolowski 1994, 1996, Wesolowski et al. 2002, 2006, 2010). However, each of these studies focused on the avifauna of the strictly protected, primeval stands. Only a few papers describe the status of selected species, e.g., the Chiffchaff Phylloscopus collybita and woodpeckers, in managed stands near the BNP (Piotrowska \& Wesolowski 1989, Wesolowski 1995, Walankiewicz et al. 2002, 2011, Wesolowski et al. 2005, Czeszczewik \& Walankiewicz 2006, Czeszczewik et al. 2013).

We present the results of a three-year study of the breeding avifauna in three different parts of the Bialowieza Forest that have experienced different levels of forest management: (1) no intervention ("natural"); (2) partially managed ("semi-natural"); and (3) intensive forestry ("managed"). Although forest management (especially removal of dead wood) in the Bialowieza Forest is known to strongly influence some bird species such as woodpeckers (Wesolowski 1995, Walankiewicz et al. 2002, 2011, Czeszczewik \& Walankiewicz 2006, Czeszczewik et al. 2013), this is the first study to attempt a wider assessment of the effects of forest management on the forest breeding bird community.

We focus specifically on how forest management has altered bird community structure (avian richness, abundance, diversity, foraging and nesting groups) in the three major types of forest found in the BNP: spruce-pine, lime-hornbeam, ash-alder stands. We assumed that the BNP represents natural conditions, and we hypothesized that simplification of the spatial structure, the felling and replanting of trees and the removal of the dead wood (Bobiec 2002, Wesolowski 2005) would simplify the structure of the bird community, as it has been demonstrated for woodpeckers (Walankiewicz et al. 2002, 2011, Czeszczewik et al. 2013). An additional aim of this study was to identify the forest habitat types that are most sensitive to current forest management practices.

\section{Material and methods}

\section{Study area}

The study was conducted in the Polish part of the Bialowieza Forest $\left(52^{\circ} 29^{\prime}-52^{\circ} 57^{\prime} \mathrm{N}\right.$ and $23^{\circ} 31^{\prime}-24^{\circ} 21^{\prime} \mathrm{E}$ ). This forest remnant survived in primeval condition because the 
whole Bialowieza Forest was protected as a royal hunting grounds beginning in the $\mathrm{XV}$ century. Logging started in 1914 but a few legacy trees remain even in heavily logged stands. The dominant forest type is deciduous lime-hornbeam (Tilio-Carpinetum) composing approximately $49 \%$ of total fores area on the fertile, mainly brown soils, with moderate wetness. Mixed coniferous sprucepine (Pino-Quercetum) occurs on approx $37 \%$ of the total forest area, exclusively on the driest sandy soils with low fertility. Alder and ash-alder forests (Carici elongatae-Alnetum, Fraxino-Alnetum) represent about $14 \%$ of forest area and grow along forest streams or in depressions with standing water.

Approximately $16 \%$ of the Bialowieza Forest has been strictly protected as the Bialowieza National Park since 1921. In addition, the Bialowieza Forest includes 21 "nature reserves" outside the national park (19\% of the total forest area) where different kinds of "sanitary" treatments (selective removal of some dead trees, small-scale plantations) are undertaken. These represent areas with relatively low intensity management. The rest of the forest is managed by State Forests that carry out logging, planting, dead wood removal, and control of forest pests (often by cutting infected trees), that represent intensive forest management. Overall, forest management in the Polish part of the Bialowieza Forest during the $\mathrm{XX}$ century consisted mainly of cutting trees $\left(150000 \mathrm{~m}^{3}\right.$ per year), although in last four years logging was reduced approximately threefold. Logging during the $\mathrm{XX}$ century led to a significant reduction in the average age of tree stands outside the BNP and nature reserves. In logged areas only a few of the oldest trees are protected as nature monuments.

\section{Sampling design}

Study plots were selected to represent the three main forest types: spruce-pine (SP), lime-hornbeam (LH) and ash-alder (AA). Plots were established in areas differing in the intensity of forest management: (1) natural, near-primeval stands of the Bialowieza National Park (NAT); (2) semi-natural nature reserves with low-intensity management (SEMI); and (3) managed stands with high intensity forest management (MAN). Labels of the plots represent the different combinations of forest type and management inten- sity in each plot: SP-NAT, SP-SEMI, SPMAN; LH-NAT, LH-SEMI, LH-MAN; AANAT, AA-SEMI, AA-MAN. The characteristics of each plot are reported in Tab. 1.

Within each of the nine plots, eight points were selected randomly with a minimum distance of $250 \mathrm{~m}$ each other and marked on the field. In total, 72 sites were marked. This design includes no replicates of the forest type/management intensity treatments. Consequently, point count locations were spatially correlated, but this did not affect results of our analyses, because we tested only for the main effects of forest and management type. No significant autocorrelation was found among plots (Moran's $I$ test) for three bird indices: abundance $(I=-0.146, \mathrm{p}$ $=0.64)$, diversity $(I=-0.116, \mathrm{p}=0.87)$ and richness $(I=-0.127, \mathrm{p}=0.78)$.

\section{Bird surveys}

During three breeding seasons (April-May, 2010-2012) point counts (Hutto et al. 1986) of all birds were carried out at each of 72 sites. Bird surveys were conducted from dawn to approximately 09:00 a.m. Three visits per season were made at each site. Surveys were conducted by experienced obser-

Tab. 1 - Characteristics of the study plots in the Bialowieza Forest grouped by stand type (AA: ash-alder stands; LH: lime-hornbeam stands; SP: spruce-pine stands) and management intensity (NAT: unmanaged stands in the Bialowieza National Park; SEMI: low intensity management in nature reserves; MAN: intensively managed stands).

\begin{tabular}{|c|c|c|c|c|}
\hline Study plot & Main tree species & Stand age & Structure of the tree stand & Human activity \\
\hline SP-NAT & $\begin{array}{l}\text { Pinus sylvestris, Picea } \\
\text { abies, Quercus robur, } \\
\text { Carpinus betulus }\end{array}$ & $\begin{array}{l}\text { Uneven aged } \\
0 \text { to } 300 \text { years } \\
\text { old }\end{array}$ & $\begin{array}{l}\text { Old growth with much dead } \\
\text { wood }\end{array}$ & $\begin{array}{l}\text { Very limited human activity for centuries, re- } \\
\text { search only, no forest management }\end{array}$ \\
\hline SP-SEMI & $\begin{array}{l}\text { Pinus sylvestris, Picea } \\
\text { abies, Quercus robur, } \\
\text { Carpinus betulus }\end{array}$ & $\begin{array}{l}\text { Some trees } 80-150 \\
\text { years old but most } \\
\text { are much younger }\end{array}$ & $\begin{array}{l}\text { Old gr } \\
\text { filled }\end{array}$ & $\begin{array}{l}\text { Tourist traffic on the trails; management lim- } \\
\text { ited to sanitary cutting of infested spruces. Re- } \\
\text { moval of dead wood from } 1921 \text { until } 2008\end{array}$ \\
\hline SP-MAN & $\begin{array}{l}\text { Pinus sylvestris, Picea } \\
\text { abies,some Quercus robur }\end{array}$ & $60-80$ years old & ged stands with & $\begin{array}{l}\text { Tourist traffic on the trails; intensive forest } \\
\text { management: clear-cuts, tree planting within } \\
\text { fenced areas }\end{array}$ \\
\hline LH-NAT & $\begin{array}{l}\text { Tilia cordata, Carpinus be- } \\
\text { tulus, Picea abies, Quercus } \\
\text { robur, Acer platanoides }\end{array}$ & $\begin{array}{l}\text { Uneven aged } \\
0-200(300) \\
\text { years old }\end{array}$ & Old growth, $\mathrm{m}$ & $\begin{array}{l}\text { Only limited tourist traffic restricted to the } \\
\text { main trail, research only; no management }\end{array}$ \\
\hline LH-SEMI & $\begin{array}{l}\text { Carpinus betulus, Tilia cor- } \\
\text { data, Picea abies, Quercus } \\
\text { robur, Acer platanoides }\end{array}$ & $\begin{array}{l}\text { Uneven aged } \\
0-200(300) \\
\text { years old }\end{array}$ & $\begin{array}{l}\text { Old growth, multi-story stand } \\
\text { with some gaps filled with } \\
\text { younger trees }\end{array}$ & $\begin{array}{l}\text { Tourist traffic on the trails; sanitary cutting of } \\
\text { infested spruces and some thick trees, removal } \\
\text { of dead wood from } 1921 \text { until } 2008\end{array}$ \\
\hline LH-MAN & $\begin{array}{l}\text { Carpinus betulus, Picea } \\
\text { abies, Quercus robur, Tilia } \\
\text { cordata }\end{array}$ & $30-40$ years old & $\begin{array}{l}\text { A few large old trees in rege- } \\
\text { nerating stands }\end{array}$ & $\begin{array}{l}\text { Tourist traffic on the trails; intensive forest } \\
\text { management: clear-cuts, tree planting within } \\
\text { fenced plots }\end{array}$ \\
\hline AA-NAT & $\begin{array}{l}\text { Alnus glutinosa, Fraxinus } \\
\text { excelsior, Picea abies }\end{array}$ & $\begin{array}{l}\text { Uneven aged } \\
0-200(300) \\
\text { years old }\end{array}$ & $\begin{array}{l}\text { Old growth, semi-open, with } \\
\text { dense shrub layer in some } \\
\text { places }\end{array}$ & $\begin{array}{l}\text { Very limited human use for centuries, research } \\
\text { only; no management }\end{array}$ \\
\hline AA-SEMI & $\begin{array}{l}\text { Alnus glutinosa, Fraxinus } \\
\text { excelsior, Picea abies }\end{array}$ & $\begin{array}{l}\text { Uneven aged } \\
0-150(200) \\
\text { years old }\end{array}$ & $\begin{array}{l}\text { Single big trees; semi-open, } \\
\text { with dense bush layer in } \\
\text { some places }\end{array}$ & $\begin{array}{l}\text { Limited to sanitary cutting of infested spruces } \\
\text { and big trees; c. } 30 \text { years ago most large trees } \\
\text { were removed, removal of dead wood from } \\
1921 \text { until } 2008 \text { year, no planting only natural } \\
\text { regeneration of trees }\end{array}$ \\
\hline AA-MAN & $\begin{array}{l}\text { Alnus glutinosa, Fraxinus } \\
\text { excelsior, Picea abies }\end{array}$ & $30-60$ years old & $\begin{array}{l}\text { More open, younger stand } \\
\text { compared to NAT and SEMI }\end{array}$ & $\begin{array}{l}\text { Selective cutting of trees every } 40-50 \text { years } \\
\text { and most of the oldest trees are removed, per- } \\
\text { manent removal of dead wood, no planting, } \\
\text { only natural regeneration of trees }\end{array}$ \\
\hline
\end{tabular}


vers only on days when the weather was good, no wind or rain (Bibby et al. 1992) During each survey at each site, the number of individuals all bird species heard and/or seen within a $50 \mathrm{~m}$ radius and greater than $50 \mathrm{~m}$, were recorded during a 10-min period. Overflying birds and wintering visitors (Bohemian waxwing, Bombycilla garrulus and Brambling, Fringilla montifringilla) were not included in analyses. At every point the maximum number of each bird species from the three counts in each year was used in analyses. Bird species detected outside of the $50-\mathrm{m}$ radius circle were used only for qualitative comparisons (e.g., assemblage composition).

Although the point method is less accurate than mapping bird territories, not allowing the estimation of the absolute density of birds (Bibby et al. 1992), the composition and relative abundance of bird species in different habitats in the BNP as revealed by point counts were similar to those obtained by the mapping territories (Wesolowski et al 2010). In addition, because the community indexes used are based on relative abundance in each habitat type, the potential influence of differences in detectability of the species among habitats was mitigated (Dawson \& Bull 1975, Verner 1985).

\section{Habitat variable}

At each point count site, tree measurements were made once during the study. Measures were taken within a square of 0.25 ha centered on the point count site. The species, diameter at the breast height (DBH) and condition (live or dead) of each standing tree $(\geq$ $10 \mathrm{~cm} \mathrm{DBH)} \mathrm{was} \mathrm{recorded} \mathrm{within} \mathrm{the} \mathrm{sam-}$ pled square, and the total basal area for each tree species in the plot was calculated. We analyzed six continuous variables: (1) the total basal area of all live trees (expressed as $\mathrm{m}^{2}$ per ha); (2) density of live trees (number of stems per ha); (3) density of live conifers (4) species diversity of live trees (ShannonWiener's index based on the number of live trees with Betula spp. and Ulmus spp. being treated at generic level); (5) basal area of standing dead trees; and (6) density of standing dead trees.

\section{Data analysis}

\section{Bird indexes}

The following indexes were calculated:

- $S$ : bird richness was calculated as the number of bird species detected at every point count site.

- $A$ : bird abundance was calculated as the number of all individuals detected at each point count site.

- $H^{\prime}$ : bird diversity per plot was calculated using Shannon-Wiener index (Shannon \& Weaver 1949).

For each site, we also calculated abundance indexes for groups of birds with common foraging and nesting habits, i.e., for foraging or nesting guilds, respectively. These guilds were distinguished following Tomialojć et al. (1984), Tomialojć \& Wesolowski (1990) with some changes by Wesolowski et al. (2010):

\section{Foraging guilds}

Birds foraging outside the forest were grouped together independently of the type of food taken, while within-forest foragers were classified as: (i) predators (hunting mainly vertebrates); (ii) herbivores (birds feeding on plants including seed eaters); and (iii) "insectivores". The last group was further subdivided into those foraging on the ground ("ground-feeders"), on the bark ("bark-feeders") or on the crown ("crownfeeders")

\section{Nesting guilds}

Three guilds were defined to reflect an increasing nest vulnerability to predators: (i) birds nesting on the ground or in low vegetation (up to $1.5 \mathrm{~m}$ above the ground), labeled as "ground-nesters"; (ii) birds building open or domed nests on high bushes or trees, labeled as "crown-nesters"; and (iii) those that nest in cavities, called "cavity-nesters". Be- cause there were no nest-boxes on our plots, cavity-nesting birds used only natural cavities. To calculate an index value for each guild (e.g., an abundance index) for a single season, we summed the number of individuals of all species in each group recorded at each site.

\section{Statistical analyses}

Data on tree-stand characteristics and abundance in nesting and foraging guilds was $\log _{10}$-transformed before analyses, because the distribution of some variables was right-skewed. A linear mixed-effects model fitted by REML was applied. Initial analyses included only plot ID as random variable. Because these analyses revealed that the sampling year was not a significant factor, we also included the year as a random variable in further analyses. In the subsequent models, all habitat characteristics, forest type and management intensity were used as fixed variables. Separate models were run using each index (bird richness, bird abundance and bird diversity) as the dependent variable. To reduce the number of analyses for foraging and nesting guilds, we used only the abundance index as dependent variable. The significance of fixed effects in the model was determined using likelihood ratio tests - LR (-2 times the difference in log-likelihoods between hierarchical models estimated using maximum likelihood, tested against a $\chi^{2}$ distribution with the number of degrees of freedom equal to the difference in the number of terms estimated). The post-hoc Tukey's HSD test was applied to estimate the significance of differences between means of indices obtained for the three consecutive years, the three main forest types (SP, LH and AA) and the three levels of management intensity (NAT, SEMI and MAN stands). All analyses were performed using the software package R (R Development Core Team 2010). Means and model coefficients are presented \pm standard error or standard deviation.

Tab. 2 - Mean $( \pm \mathrm{SD})$ and sample size of bird indices: richness $(\mathrm{S})$, abundance $(A)$, diversity $\left(\mathrm{H}^{\prime}\right)$ in all study plots representing three forest types (spruce-pine, lime-hornbeam, ash-alder) and three levels of management intensity (NAT: natural, near-primeval forest, Bialowieza National Park; SEMI: semi-natural forest, nature reserves; MAN: intensively managed forest).

\begin{tabular}{|c|c|c|c|c|c|c|c|}
\hline \multirow{2}{*}{ Forest type } & \multirow{2}{*}{ Bird indices } & \multicolumn{2}{|c|}{ NAT } & \multicolumn{2}{|c|}{ SEMI } & \multicolumn{2}{|c|}{ MAN } \\
\hline & & Mean \pm SD & $\mathbf{N}$ & Mean \pm SD & $\mathbf{N}$ & Mean \pm SD & $\mathbf{N}$ \\
\hline \multirow[t]{3}{*}{ Spruce-pine } & Species richness (S) & $12.0 \pm 1.69$ & 8 & $11.0 \pm 1.87$ & 8 & $9.9 \pm 0.83$ & 8 \\
\hline & Birds abundance (A) & $15.2 \pm 2.02$ & 8 & $15.0 \pm 1.91$ & 8 & $13.3 \pm 1.23$ & 8 \\
\hline & Species diversity $\left(\mathrm{H}^{\prime}\right)$ & $3.4 \pm 0.20$ & 8 & $3.3 \pm 0.26$ & 8 & $3.1 \pm 0.11$ & 8 \\
\hline \multirow[t]{3}{*}{ Lime-hornbeam } & Species richness (S) & $12.4 \pm 1.50$ & 8 & $14.2 \pm 1.50$ & 8 & $12.1 \pm 2.01$ & 8 \\
\hline & Birds abundance (A) & $17.0 \pm 2.64$ & 8 & $18.5 \pm 1.33$ & 8 & $15.0 \pm 3.17$ & 8 \\
\hline & Species diversity $\left(\mathrm{H}^{\prime}\right)$ & $3.5 \pm 0.17$ & 8 & $3.7 \pm 0.16$ & 8 & $3.5 \pm 0.24$ & 8 \\
\hline \multirow[t]{3}{*}{ Ash-alder } & Species richness (S) & $16.9 \pm 1.59$ & 8 & $15.8 \pm 2.13$ & 8 & $12.2 \pm 2.15$ & 8 \\
\hline & Birds abundance (A) & $22.6 \pm 1.40$ & 8 & $20.1 \pm 2.69$ & 8 & $14.6 \pm 2.29$ & 8 \\
\hline & Species diversity $\left(\mathrm{H}^{\prime}\right)$ & $3.9 \pm 0.14$ & 8 & $3.9 \pm 0.20$ & 8 & $3.5 \pm 0.31$ & 8 \\
\hline
\end{tabular}


Tab. 3 - Summary of statistics ( $z$-values of Tukey's HSD post-hoc test) for the effect of management regime and forest type on bird indices richness (S), abundance (A), diversity $\left(\mathrm{H}^{\prime}\right)$ and index of abundance for different feeding and nesting guilds. (AA): ash-alder stands; (LH): lime-hornbeam stands; (SP): spruce-pine stands; (NAT): natural, near-primeval areas of the Bialowieza National Park; (SEMI): semi-natural areas in nature reserves; (MAN): intensively managed areas); ('): $\mathrm{p}<0.10 ;\left(^{*}\right) \mathrm{p}<0.05 ;(* *)$ : $\mathrm{p}<0.01 ;(* * *)$ : $\mathrm{p}<0.001$.

\begin{tabular}{|c|c|c|c|c|c|c|c|c|c|c|c|c|c|}
\hline \multirow[b]{2}{*}{ Effects } & \multirow[b]{2}{*}{ Stands } & \multirow[b]{2}{*}{ 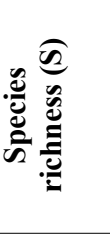 } & \multirow[b]{2}{*}{ 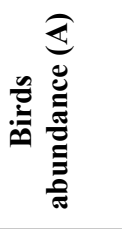 } & \multirow[b]{2}{*}{ 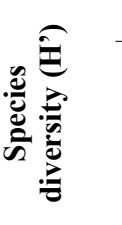 } & \multicolumn{9}{|c|}{ Index of abundance } \\
\hline & & & & & 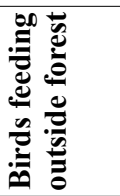 & 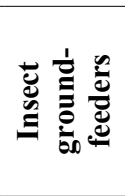 & 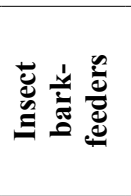 & 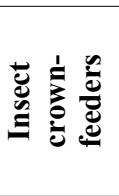 & 党 & 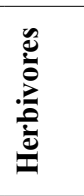 & 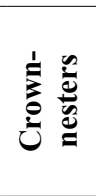 & 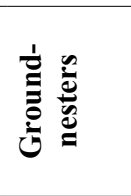 & 芳苛 \\
\hline \multirow{3}{*}{$\begin{array}{l}\text { Manage- } \\
\text { ment } \\
\text { regime }\end{array}$} & NAT-SEMI & 0.23 & 0.53 & 0.13 & 1.47 & -0.11 & -0.02 & 0.81 & -0.32 & -0.53 & -1.12 & 0.01 & $2.06^{\prime}$ \\
\hline & NAT-MAN & $4.34 * * *$ & $5.64 * * *$ & $3.75 * * *$ & $2.20^{\prime}$ & $3.31 * *$ & $4.13^{* * *}$ & $3.75^{* * *}$ & 0.32 & 0.27 & 0.48 & $2.52 *$ & $5.94 * * *$ \\
\hline & SEMI-MAN & $4.12 * * *$ & $5.11 * * *$ & $3.88 * * *$ & 0.73 & $3.41^{* *}$ & $4.15^{* * *}$ & $2.94 * *$ & 0.63 & 0.80 & 1.60 & $2.51^{*}$ & $3.88 * * *$ \\
\hline \multirow{3}{*}{$\begin{array}{l}\text { Forest } \\
\text { type }\end{array}$} & AA-LH & $3.79 * * *$ & $3.22 * *$ & $3.01 * *$ & 0.99 & $3.74 * * *$ & $2.81 *$ & 1.31 & -0.20 & -0.79 & -0.87 & $5.34 * * *$ & 1.74 \\
\hline & AA-SP & $7.27 * * *$ & $6.48^{* * *}$ & $7.89^{* * *}$ & $3.60 * * *$ & $7.04^{* * *}$ & $3.73 * * *$ & $2.27^{\prime}$ & 0.85 & 0.43 & 1.58 & $3.36^{* *}$ & $5.18 * * *$ \\
\hline & LH-SP & $3.48 * *$ & $3.26^{* *}$ & $4.89 * * *$ & $2.61^{*}$ & $3.30^{* *}$ & 0.92 & 0.96 & 1.05 & 1.22 & $2.45^{*}$ & -1.98 & $3.44 * *$ \\
\hline
\end{tabular}

\section{Results}

Bird abundance $(\mathrm{LR}=4.97, \mathrm{df}=2, \mathrm{p}=$ $0.08)$ and bird diversity $(\mathrm{LR}=-1.31, \mathrm{df}=2$, $\mathrm{p}=0.52)$ did not differ significantly among years after adjusting for the effect of management intensity and forest type. Only the index of avian richness differed significantly among years $(\mathrm{LR}=7.15, \mathrm{df}=2, \mathrm{p}=0.03)$, due to slightly higher values for the year 2011 in comparison with the year 2010 (Tukey's HSD $z=2.39, p=0.05$ ). For the sake of simplicity we used the year as a random variable in all further analyses, assuming that the difference in richness index was small enough and did not substantially affected final results.

Forest management intensity affected the bird community, with lowest $\mathrm{S}, \mathrm{A}$ and $\mathrm{H}^{\prime}$ indexes occurring typically in intensively managed stands (Tab. 2); semi-natural and natural stands usually did not differ significantly in these indexes. The composition of the bird community was similar in all study plots. Species lists for each plot are given in Tab. S1-S9 of Appendix 1. Bird abundance was significantly higher in NAT and SEMI forests than in MAN stands (Tukey's HSD, $p$ $<0.001$ for both comparisons), but NAT and SEMI forests did not differ significantly $(\mathrm{p}=$ 0.86 - Tab. 3). Species richness $(\mathrm{p}<0.001$ for both comparisons) and species diversity ( $p<0.001$ for both comparisons) were also higher in NAT and SEMI forests than in MAN stands. Again the difference between NAT and SEMI stands was not significant ( $p$ $=0.97$ and $p=0.99$ for index of species richness and species diversity, respectively Tab. 3).

Over $80 \%$ of breeding birds in all study plots feed on invertebrates (including crownforagers accounting for $42-49 \%$ of individuals), while herbivores were only $10-16 \%$ of the community assemblages (Tab. 4). The abundance of birds classified to the different foraging guilds did not differ significantly among the forest management levels, except for insectivorous species. Mean abundance of insectivorous ground-feeders, bark-feeders and crown-feeders was higher both in NAT and SEMI forest than in intensively managed forest (Tukey's HSD, $\mathrm{p}<0.001$ for both comparisons), but abundance of insectivorous birds did not differ between NAT and SEMI forests $(\mathrm{p}=0.91$ - Tab. 3).

The proportion of ground-nesters ranged from 22 to $35 \%$ and was the highest in SPNAT and the lowest in LH-NAT and in LHSEMI. The proportion of cavity-nesters ranged from 25 to $40 \%$ and was the highest in AA-NAT and the lowest in SP-MAN (Tab. 4). The abundance of birds nesting in the crowns was not significantly affected by the management zone. Cavity-nesters were less abundant in MAN forests than in NAT and SEMI forests (Tukey's HSD, $p<0.001$ for both comparisons). There was no significant difference between NAT and SEMI forest in the abundance of birds belonging to this nesting group $(\mathrm{p}=0.10$ - Tab. 3$)$.

Forest types differed in the number of bird species detected, with highest $\mathrm{S}, \mathrm{A}, \mathrm{H}^{\prime}$ indexes typically recorded in ash-alder stands. Lowest values of these parameters occurred in spruce-pine stands (Tab. 2). Bird abundance was significantly higher in AA forest

Tab. 4 - Total bird abundance (mean ha ${ }^{-1} \pm \mathrm{SE}$ ) in foraging and nesting guilds for birds sampled during 2010-2012 in the Bialowieza Forest, Poland. (AA): ash-alder stands; (LH): lime-hornbeam stands; (SP): spruce-pine; (NAT): natural, near-primeval stands of the Bialowieza National Park; (SEMI): semi-natural stands in nature reserves; (MAN): managed stands.

\begin{tabular}{|c|c|c|c|c|c|c|c|c|c|c|}
\hline \multirow{2}{*}{ Groups } & \multirow{2}{*}{ Variables } & \multicolumn{3}{|c|}{ Spruce-pine (SP) } & \multicolumn{3}{|c|}{ Lime-hornbeam (LH) } & \multicolumn{3}{|c|}{ Ash-alder (AA) } \\
\hline & & NAT & SEMI & MAN & NAT & SEMI & MAN & NAT & SEMI & MAN \\
\hline \multirow{6}{*}{$\begin{array}{l}\text { Fora- } \\
\text { ging } \\
\text { groups }\end{array}$} & $\begin{array}{l}\text { Forage } \\
\text { outside forest }\end{array}$ & $0.09 \pm 0.08$ & $0.02 \pm 0.00$ & 0 & $0.28 \pm 0.04$ & $0.41 \pm 0.08$ & $0.38 \pm 0.08$ & $0.96 \pm 0.30$ & $0.36 \pm 0.08$ & $0.13 \pm 0.00$ \\
\hline & Predators & $0.15 \pm 0.08$ & $0.08 \pm 0.02$ & 0 . & 0.08 & 0.26 & 0.13 & 0.18 & 0.12 & 0.12 \\
\hline & Herb & & 2.0 & 2.09 & 2.16 & & & & .69 & 0.24 \\
\hline & $\begin{array}{l}\text { Ground } \\
\text { insectivores }\end{array}$ & $4.53=$ & 4.64 & 3.79 & 5.35 & 5.69 & 4.94 & 7.21 & .26 & 5.3 \\
\hline & $\begin{array}{l}\text { Bark } \\
\text { insectivores }\end{array}$ & $1.39 \pm 0.05$ & $1.13 \pm 0.21$ & $0.82 \pm 0.26$ & $1.35 \pm 0.27$ & $1.91 \pm 0.16$ & $0.66 \pm 0.16$ & $2.48 \pm 0.51$ & $2.20 \pm 0.19$ & $1.07 \pm 0.10$ \\
\hline & $\begin{array}{l}\text { Crown } \\
\text { insectivores }\end{array}$ & $7.42 \pm 0.50$ & $7.10 \pm 0.60$ & $6.50 \pm 0.54$ & $7.78 \pm 0.68$ & $7.98 \pm 0.49$ & $6.60 \pm 0.62$ & $9.43 \pm 0.65$ & $8.43 \pm 0.31$ & $6.32 \pm 0.60$ \\
\hline
\end{tabular}

\begin{tabular}{lllllllllll}
\hline Nesting Ground-nesters $5.28 \pm 0.33$ & $4.45 \pm 0.60$ & $3.75 \pm 0.99$ & $3.65 \pm 0.50$ & $4.01 \pm 0.19$ & $3.75 \pm 0.14$ & $5.90 \pm 0.79$ & $6.37 \pm 0.32$ & $4.71 \pm 0.42$
\end{tabular} $\begin{array}{lllllllllllll}\text { groups } & \text { Crown-nesters } & 4.83 \pm 0.36 & 6.53 \pm 0.58 & 6.08 \pm 0.67 & 6.88 \pm 0.77 & 7.70 \pm 0.51 & 6.65 \pm 0.99 & 7.48 \pm 0.15 & 6.70 \pm 0.86 & 5.71 \pm 0.48\end{array}$ \begin{tabular}{llllllllll} 
Cavity-nesters & $5.00 \pm 0.62$ & $4.02 \pm 0.48$ & $3.35 \pm 0.35$ & $6.33 \pm 0.23$ & $6.55 \pm 0.82$ & $4.38 \pm 0.37$ & $8.91 \pm 0.55$ & $6.75 \pm 0.27$ & $4.07 \pm 0.38$ \\
\hline
\end{tabular} 
than in LH and SP forests (Tukey's HSD, p $=0.004$ and $p<0.001$, respectively), and also in LH forest than in SP forest $(\mathrm{p}=$ 0.003, Tab. 3).

The abundance of birds feeding outside the forest was significantly higher in LH and AA forest types than in SP forest (Tukey's HSD, $\mathrm{p}=0.02$ and $\mathrm{p}<0.001$, respectively - Tab. $3)$. It was related mainly to presence of the Starling Sturnus vulgaris in deciduous stands (see Tab. S6-S8 in Appendix 1). The guild of insectivorous ground-feeders was least abundant in spruce-pine forest, significantly more numerous in lime-hornbeam forest $(p=0.002)$ and most abundant in ashalder forest $(\mathrm{p}<0.001$, for difference between AA and SP forest and AA and LH forest). Also, insectivorous bark-feeders were more abundant in AA forest than in SP forest $(p<0.001)$ and LH forest $(p=0.01)$, but there was no significant difference between LH and SP forests $(p=0.62-$ Tab. 4). The abundance of crown-feeders, predators and herbivores did not differ significantly among forest types (Tab. 3).

The abundance of ground-nesters was significantly higher in AA forest than in $\mathrm{LH}$ forest (Tukey's HSD, $\mathrm{p}<0.001$ ) and SP forest $(p=0.002)$. The abundance of cavitynesters was also lower in SP forest than in LH forest and AA forest ( $p=0.002$ and $p<$ 0.001 , respectively), but not in lime-hornbeam forest compared with the ash-alder forest $(p=0.19-$ Tab. 3$)$. The abundance of birds nesting in the crowns was not significantly affected by the forest type.

The effect of vegetation structure was estimated after adjusting for the effect of main factors (forest type and management intensity). Among them, only total basal area of live trees and tree density significantly affected bird abundance. Basal area of live trees had positive effect on abundance of birds $(\mathrm{LR}=9.87, \mathrm{df}=1, \mathrm{p}=0.002$ - Fig. 1$)$. The density of live trees negatively affected bird abundance (LR $=17.01$, df $=1, \mathrm{p}<$ 0.001 - Fig. 2). The density of live trees also negatively affected species richness (LR $=$ $9.52, \mathrm{df}=1, \mathrm{p}=0.002)$, but not species diversity $(\mathrm{LR}=-2.03, \mathrm{df}=1, \mathrm{p}=0.15)$. Tree density effects may have been underlying the observed differences in tree species compo-

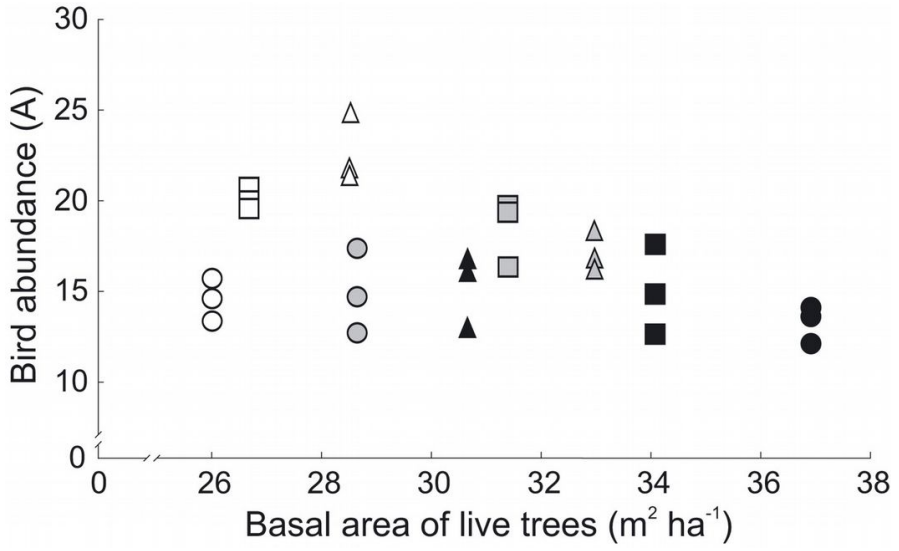

Fig. 1 - Relationship between bird abundance and basal area of live trees in 2010-2012. Different shapes represent different intensity of forest management: circles - MAN (intensively managed stands); squares - SEMI (semi-natural areas); triangles - NAT (natural, nearprimeval stands of the Bialowieza National Park). Colors represent forest stand types: black SP (spruce-pine); grey - LH (lime-hornbeam); white - AA (ash-alder).

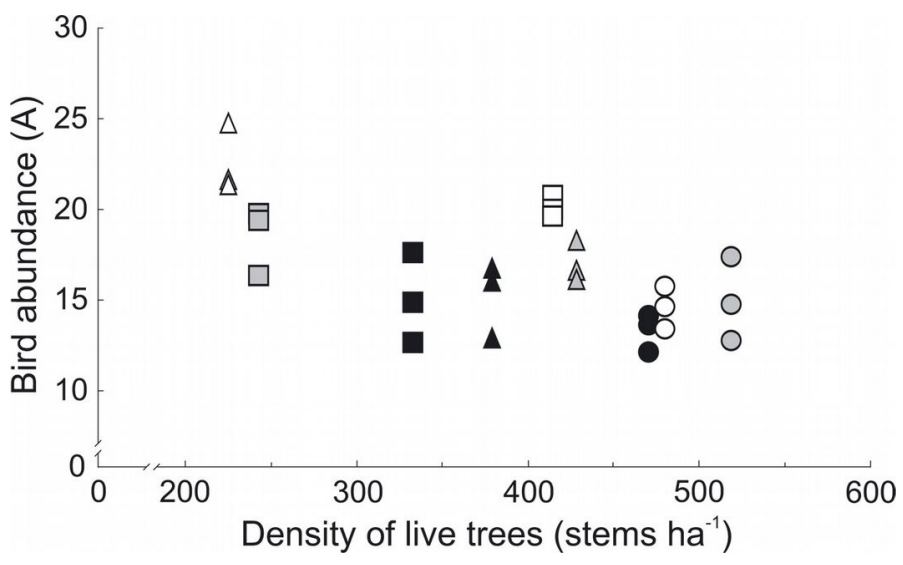

Fig. 2 - Relationship between bird abundance and density of live trees in 2010-2012. Different shapes represent different intensity of forest management: circles - MAN (intensively managed stands); squares - SEMI (semi-natural areas); triangles - NAT (natural, nearprimeval stands of the Bialowieza National Park). Colors represent forest stand types: black SP (spruce-pine); grey - LH (lime-hornbeam); white - AA (ash-alder).

sition and management intensity, as the density of conifers was significantly higher in MAN stands and SEMI stands in comparison with NAT stands (Tukey's HSD, p < 0.001, for both comparisons - Fig. 3a, Tab. $5)$.
Basal area of standing dead trees differed significantly among all the three levels of management intensity, being higher in NAT and SEMI stands than in MAN stands (Tukey's HSD, $p<0.001$ and $p=0.03$, respectively), and also was significantly higher

Tab. 5 - Summary of statistics ( $z$-values of Tukey's HSD post-hoc test) for the effect of management regime and forest type on tree species composition. (AA): ash-alder stands; (LH): lime-hornbeam stands; (SP): spruce-pine stands; (NAT): natural, near-primeval areas of the Bialowieza National Park; (SEMI): semi-natural areas in nature reserves; (MAN): intensively managed areas; $\left({ }^{\prime}\right)$ : $p<0.10 ;(*) p<0.05 ;(* *)$ : $\mathrm{p}<0.01 ;(* * *): \mathrm{p}<0.001$.

\begin{tabular}{|c|c|c|c|c|c|c|c|}
\hline Effects & Stands & $\begin{array}{c}\text { Live trees } \\
\text { density }\end{array}$ & $\begin{array}{l}\text { Live trees } \\
\text { basal area }\end{array}$ & $\begin{array}{l}\text { Conifers } \\
\text { density }\end{array}$ & $\begin{array}{l}\text { Dead trees } \\
\text { density }\end{array}$ & $\begin{array}{l}\text { Dead trees } \\
\text { basal area }\end{array}$ & $\begin{array}{l}\text { Live trees } \\
\text { diversity }\end{array}$ \\
\hline \multirow[t]{3}{*}{ Management } & NAT-SEMI & $-9.23 * * *$ & $-8.82 * * *$ & $-6.55 * * *$ & 0.34 & $9.54 * * *$ & -0.27 \\
\hline & NAT-MAN & $-12.08 * * *$ & $-6.70 * * *$ & $-6.44 * * *$ & $2.81 *$ & $12.34 * * *$ & -0.56 \\
\hline & SEMI-MAN & $-3.00 * *$ & 1.93 & -0.15 & $2.40 *$ & $2.52 *$ & -0.28 \\
\hline \multirow[t]{3}{*}{ Forest type } & AA-LH & -0.07 & $-3.09 * *$ & 0.01 & $5.93 * * *$ & $4.87 * * *$ & $2.26^{\prime}$ \\
\hline & AA-SP & $2.13^{\prime}$ & $-2.14^{\prime}$ & $-14.28 * * *$ & $3.79 * * *$ & 1.52 & $12.26^{* * *}$ \\
\hline & LH-SP & $2.20^{\prime}$ & 0.91 & $-14.29 * * *$ & $-2.40 *$ & $-3.69 * * *$ & $9.89 * * *$ \\
\hline
\end{tabular}



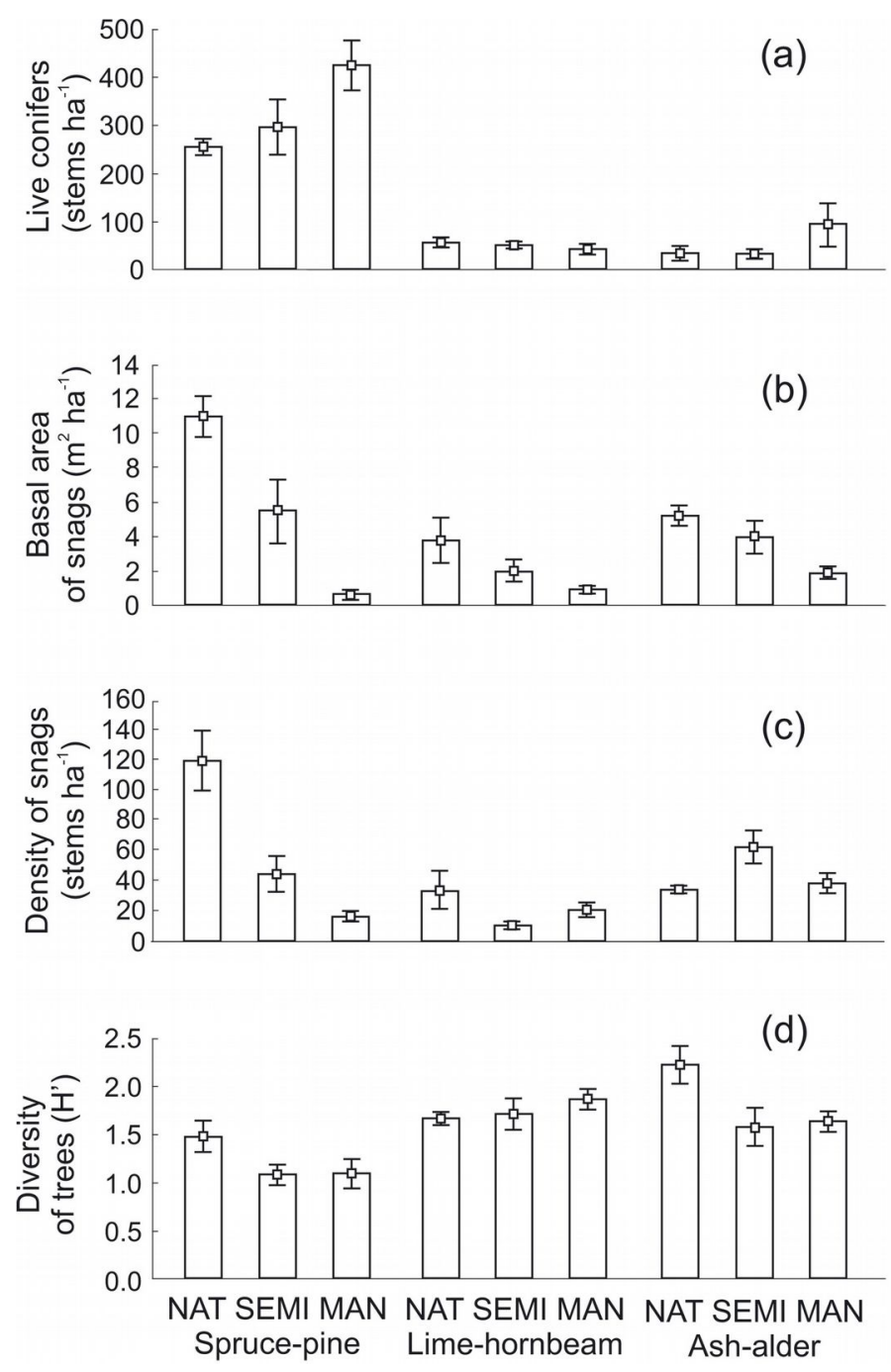

Fig. 3 - Structural parameters of the three forest stands across three levels of forest management. (a): Density of coniferous trees; (b) basal area of dead trees; (c): density of standing dead trees; (d) diversity of live trees. Forest types: (SP) spruce-pine; (LH) lime-hornbeam; (AA) ash-alder. Management intensities: (NAT) natural; (SEMI) semi-natural; (MAN): managed.

in NAT stands than in SEMI stands $(\mathrm{p}<$ 0.001 - Fig. 3b, Tab. 5). The density of dead trees was lower in MAN stands than in NAT stands $(\mathrm{p}=0.01)$ and SEMI stands $(\mathrm{p}=$ $0.04)$, but there was no significant difference between NAT and SEMI stands $(\mathrm{p}=0.94$ Fig. 3c, Tab. 5).

Regarding forest type, density of conifers was significantly higher in SP forest than in LH and AA forests (Tukey's HSD, $\mathrm{p}<0.001$ for both comparisons - Tab. 5). In addition, species diversity of trees was lower in SP forest when compared with the other two forest types $(p<0.001$ for both comparisons with LH and AA forests, respectively - Fig. 3d, Tab. 5). Basal area of standing dead trees was higher in SP forest than in LH forest (p $<0.001$ ) and AA forest than LH forests ( $\mathrm{p}<$ 0.001 ), but not in AA forest in comparison with SP forests $(p=0.28$ - Fig. $3 b)$. The den- sity of dead trees was also significantly higher in SP and AA forests than in LH forest ( $p=0.04$ and $p<0.001$, respectively), but was also higher in AA than in SP forest ( $p<0.001$ - Fig. 3c, Tab. 5).

\section{Discussion}

Forest management affected stand characteristics that are important to birds. The density of trees, their total basal area and the tree species diversity each influenced one or more bird community indexes. The density of dead trees was significantly higher in NAT in comparison with SEMI and MAN stands. The loss of dead wood was the most visible in SP-MAN plots in comparison to SP-NAT stands (Fig. 3b, Fig. 3c). The highest number of dead trees (mostly spruces) were found in SP-NAT stands because of the mortality associated with the climate war- ming that has been ongoing at BNP since many years (Kowalski 1982, Bernadzki et al. 1998, Walankiewicz 2002). Outside BNP forest managers try to minimize the effects of these changes by removing all infected and dying trees. Although the density of dead trees did not directly influence bird community indexes, it is known that some bird species are strongly dependent on dead wood (e.g., White-backed Woodpecker Dendrocopos leucotos, Three-toed Woodpecker Picoides tridactylus). In addition, the presence of snags shapes the forest structure, as dying trees create canopy gaps where natural regeneration takes place. Dead wood in various stages of decay, including single dead trees of pioneer species (e.g., birch, Betula spp. and aspen, Populus tremula), are important nesting spots for many bird species including woodpeckers. The root disk of fallen trees also provides nesting sites for many bird species (Tomialojć et al. 1984). Consequently, bird abundance and species richness within treefall gaps is higher than in closecanopy forest (Fuller 2000). Such gaps are fairly common in BNP (NAT plots in contrast to MAN plots), where older trees are regularly cut by foresters and replaced mainly by pines and oaks, often planted in fenced gaps. Such planting is the reason underlying the highest density of coniferous trees occurring in the SP-MAN plots.

Bird community indexes are also affected by the forest structure. The richness, abundance and diversity of bird communities was the highest in natural or in semi-natural stands and the lowest in managed stands. In semi-natural forests where management impacts are very moderate, bird indexes did not differ significantly from those found in the BNP (NAT plots). This indicates that silvicultural practices (logging, planting trees, etc.) led to the decline of some specialized bird species (Wesolowski 1995), but some common species, e.g., Chaffinch Fringilla coelebs in coniferous managed stands, seem to have taken advantage of forest management (see Tab. S1-S3 in Appendix 1).

Analyses of nesting guilds revealed that forest management negatively influenced the abundance of cavity-nesters. Significantly lower tree cavity density occurred in managed stands compared to natural stands of the BNP (unpublished data, Walankiewicz et al. 2014). The high total basal area of deciduous trees in NAT plots suggests a much higher proportion of large, old trees, where typically more cavities may be found. The Collared Flycatcher Ficedula albicollis, the most common cavity-nester in BNP, chooses nesting cavities in trees with an average DBH of $43 \mathrm{~cm}$ (Walankiewicz et al. 2007). Consequently, the conservation of large deciduous trees and snags is important for maintaining the current and future resources for cavity-nesters (Kikuchi et al. 2013). Tree 
cavities are at risk in harvested forests where large, old trees are eliminated by logging, and it takes more than a century to be replaced (Edworthy \& Martin 2013).

Analysis of foraging guilds showed that forest management mostly affected insectivorous bird species, whereas the abundance of the other foraging groups did not differ significantly between natural and semi-natural forests. Most of the breeding bird species in each study plot were insectivorous, and insects and other invertebrates such as snails can affect breeding density of birds (Rosenvald et al. 2011). Typically caterpillar biomass is much higher in BNP compared with other temperate deciduous forests (Rowinsk 2001), and the density of winter moth Operophtera brumata (the most important food for birds during breeding - Cholewa \& Wesolowski 2011) was much higher in primeva forest than in intensively managed stands (Wesolowski \& Rowinski 2006). Older trees also create a more diverse forest structure in comparison to younger ones (more dead and dying parts, more cracks and irregularities, etc.), leading to a higher invertebrate species richness in the unmanaged BNP with many old trees. Forest management, therefore, can also negatively affect various groups of invertebrates (Hill \& Roberts 1990, Schowalter 1990, Spitzer et al. 2008).

The highest values of the avian community indexes (richness, abundance, diversity) were found in AA-NAT and the lowest in SP-MAN managed spruce-pine forest. Bird communities in AA stands usually show the highest species richness and coniferous stands the lowest (Tomialojć et al. 1984 Wesolowski et al. 2010). However, this difference was not apparent in intensively managed stands, where the avian indexes were the highest in lime-hornbeam (LH) and the lowest in spruce-pine (SP) stands. This sug gests that ash-alder stands in the Bialowieza forest were more affected by forest manage ment than lime-hornbeam stands, and the primary effect of management was to reduce the basal area of live trees, that was the lowest in AA-MAN compared with other investigated plots (Fig. 2d). The basal area of live trees was significantly associated with bird densities. AA stands are found in swampy areas and typically support a low density of large trees. Logging even a small number of these large trees may result in a remarkable change in basal area and forest structure compared with other forest types (Tab. 4).

Since early 1990s the ash-alder stands were seriously affected by ash dieback disease (Chalara fraxinea) in the Bialowieza Forest, and many ash trees are currently dead or dying (Przybyl 2002). It is likely that the proportion of such species will be significantly reduced in the near future, also affecting bird communities. Ash is one of the most impor tant cavity tree for cavity-nesters in ash-alder stands (Wesolowski 2011, 2012). On the other hand, some bird species may benefit from increased resources of dead wood, at least where snags are not removed as in managed stands.

The basal area of live trees had a significant positive effect on the total abundance of birds in the stand, but the effect of live tree density was negative, i.e., both the species richness and diversity of birds were lower where the density of live trees was high. This suggests that intensive management practices, such as rotational cutting, planting and also partially natural regeneration, may lower habitat quality for many bird species. It is obvious that younger trees offer less diverse nest sites (e.g., cavities) and foraging possibilities (lack of rough bark, dead branches, big crowns). Rare woodpeckers prefer foraging on large diameter trees, with dead parts or trees with rough, richly-tectured bark. Results of many studies support the importance of mature large trees for sustaining the richness of bird communities (Nilsson et al. 2002, Ellison et al. 2005, Roberge et al. 2008, Ghadiri Khanaposhtani et al. 2013), and bird species richness has been reported to decline with intensive forest management (Durães et al. 2013, Toyoshima et al. 2013).

It is worth stressing that since the 1920 s through the 1980s forest managers often clear-cut stands (mostly coniferous stands) in the Bialowieza forest, though such practice is no longer allowed. In the 1990s, several 2-3 ha clearings were created in the Bialowieza Forest in order to sustain some bird species that were scarce or absent in oldgrowth stands (Fuller 1995).

In summary, our results show that some stand types (e.g., ash-alder) are more sensitive to forest management than others, and the bird community of these ecosystems may be deeply affected by the currently intensive management practices. However, almost all bird community indexes in SEMI stands were similar to those obtained in NAT forest, indicating that silvicultural practices targeted at sustaining forest health have a limited effect on local bird communities.

\section{Conservation implications}

Although we found significant differences among the stand types and levels of management intensity in the amount of dead wood, no direct effect of these differences on the avian communities of these stands were observed. However, it is well known that some endangered species of birds are susceptible to the removal of dead trees (Wesolowski et al. 2005, Czeszczewik \& Walankiewicz 2006, Roberge et al. 2008) and study from forests in Estonia showed that the abundance of coarse woody debris was the main factor affecting the bird community (Rosenvald et al. 2011)
Forestry practices in the Bialowieza Forest have caused noticeable changes in tree species composition and decreased snag density. Our results emphasize the importance of mature forests for multiple bird species, highlighting how intensive forest management prcatices (e.g., removal of dead wood, tree planting) may reduce the forest conservation value. Nonetheless, the Bialowieza forest still show a high bird diversity and abundance, and is currently considered one of the main biodiversity hotspot in Europe (e.g., all but one European woodpeckers breed there). However, a significant portion of old-growth stands has not been currently excluded from management activities in the 2012-2021 plans.

Our results suggest the lack of intensive management activities (no cutting, semicommercial thinning or planting trees) as an effective strategy to maintain the natural forest biodiversity. In most Polish national parks, naturalization practices often result in the removal of pioneer tree species (aspen and birch) that are essential for the foraging and breeding of different bird species, e.g., White-backed Woodpecker. Removal of these pioneer species leads to a decline in biodiversity of protected areas (DeByle \& Winokur 1985). Although long-lasting directional changes in spruce-pine and lime-hornbeam stands are inevitable due to natural and anthropogenic climate changes, we did find no basis for either inhibiting or accelerating such changes by silvicultural practices in any of the three different forest types analyzed.

\section{Acknowledgements}

This research was funded by the National Center of Science in Poland (National Science Center Grant NN304 218437). We heartily thank to R. J. Fuller, N. L. Rodenhouse and one anonymous reviewer for valuable comments on an earlier version of the manuscript.

\section{References}

Bernadzki E, Bolibok L, Brzeziecki B, Zajaczkowski J, Zybura H (1998). Rozwój drzewostanów naturalnych Bialowieskiego Parku Narodowego w okresie 1936 do 1996 [Development of natural forest stands in the Białowieża National Park in the period of 1936 to 1996]. Fundacja Rozwój SGGW, Warszawa, Poland, pp. 271. [in Polish]

Bibby CJ, Burgess ND, Hill DA (1992). Bird census techniques. Academic Press, London, UK, pp. 257.

Bobiec A (2002). Living stands and dead wood in the Bialowieza forest: suggestions for restoration management. Forest Ecology and Management 165: 125-140. - doi: 10.1016/S0378-1127(01)00 655-7

Cholewa M, Wesolowski T (2011). Nestling food of European hole-nesting passerines: do we know enough to test the adaptive hypotheses on 
breeding seasons? Acta Ornithologica 46: $105-$ 116. - doi: 10.3161/000164511X625874

Czeszczewik D, Walankiewicz W (2006). Logging affects the white-backed woodpecker Dendrocopos leucotos distribution in the Bialowieza Forest. Annales Zoologici Fennici 43: 221-227. [online] URL: http://pracownia.org.pl/

Czeszczewik D, Walankiewicz W, Mitrus C, Tumiel T, Stanski T, Sahel M, Bednarczyk G (2013). Importance of dead wood resources for woodpeckers in coniferous stands of the Bialowieza Forest. Bird Conservation International 23: 414-425. - doi: 10.1017/S0959270912000354

Dawson DG, Bull PC (1975). Counting birds in New Zealand forests. Notornis 22: 101-109.

DeByle NV, Winokur RP (1985). Aspen: ecology and management in the western United States. Gen. Tech. Report RMRS-GTR-119, Rocky Mountain Research Station, USDA Forest Service, Fort Collins, CO, USA, pp. 283. [online] URL: http://digitalcommons.usu.edu/aspen_bib/ 6964/

Diaz I, Armesto JJ, Reid S, Sieving KE, Willson MF (2005). Linking forest structure and composition: avian diversity in successional forests of Chiloe Island, Chile. Biological Conservation 123: 91-101. - doi: 10.1016/j.biocon.2004.10. 011

Durães R, Carrasco L, Smith TB, Karubian J (2013). Effects of forest disturbance and habitat loss on avian communities in a Neotropical biodiversity hotspot. Biological Conservation 166: 203-211. - doi: 10.1016/j.biocon.2013.07.007

Edworthy AB, Martin K (2013). Persistence of tree cavities used by cavity-nesting vertebrates declines in harvested forests. Journal of Wildlife Management 77: 770-776. - doi: 10.1002/jwmg. 526

Ellison AM, Bank MS, Clinton BD, Colburn EA, Elliot K, Ford CR, Foster DR, Kloeppel BD, Knoepp JD, Lovett GM, Mohan J, Orwig DA, Rodenhouse NL, Sobczak WV, Stinson KA, Stone JK, Swan CM, Thompson J, Von Holle B, Webster JR (2005). Loss of foundation species: consequences for the structure and dynamics of forested ecosystems. Frontiers in Ecology and the Environment 3: 479-486. - doi: 10.1890/15 40-9295(2005)003[0479:LOFSCF]2.0.CO;2

Fuller RJ (1995). Bird life of woodland and forest. Cambridge University Press, Cambridge, UK, pp. 244.

Fuller RJ (2000). Influence of treefall gaps on distributions of breeding birds within interior oldgrowth stands in Bialowieza forest, Poland. Condor 102: 267-274. - doi: 10.1650/0010-5422(20 00)102[0267:IOTGOD]2.0.CO;2

Ghadiri Khanaposhtani M, Kaboli M, Karami M, Etemad V, Baniasadi S (2013). Effects of logged and unlogged forest patches on avifaunal diversity. Environmental Management 51: 750-758. doi: 10.1007/s00267-012-9979-2

Gregory RD, Van Strien A (2010). Wild bird indicators: using composite population trends of birds as measures of environmental health. Ornithological Science 9: 3-22. - doi: 10.2326/osj. 9.3
Hauer G, Cumming S, Schmiegelow F, Adamowicz W, Weber M, Jagodzinski R (2010). Tradeoffs between forestry resource and conservation values under alternate policy regimes: a spatial analysis of the western Canadian boreal plains. Ecological Modelling 221: 2590-2603. - doi: 10.1016/j.ecolmodel.2010.07.013

Hill D, Roberts P (1990). Densities and biomass of invertebrates in stands of rotationally managed coppice woodland. Biological Conservation 51: 167-837. - doi: 10.1016/0006-3207(90)901 49-J

Hutto RL, Pletschet SM, Hendricks P (1986). A fixed-radius point count method for nonbreeding and breeding season use. The Auk 103: 593-602. [online] URL: http://www.jstor.org/stable/4087 132

Keller JK, Richmond ME, Smith CR (2003). An explanation of patterns of breeding bird species richness and density following clearcutting in northeastern USA forests. Forest Ecology and Management 174: 541-564. - doi: 10.1016/S03 78-1127(02)00074-9

Kikuchi K, Akasaka T, Yamaura Y, Nakamura F (2013). Abundance and use of cavity trees at the tree- and stand-levels in natural and plantation forests in Hokkaido. Japan Journal of Forest Research 18: 389-397. - doi: 10.1007/s10310-0120358-x

Kowalski M (1982). Rozwój drzewostanów naturalnych na powierzchni badawczej w Bialowieskim Parku Narodowym [Development of natural forest stands on an experimental area in the Bialowieza National Park.]. Rozprawy naukowe i monografie, Wydawnictwo SGGW, Warszawa, Poland, pp. 87. [in Polish]

Larsen S, Sorace A, Mancini L (2010). Riparian bird communities as indicators of human impacts along Mediterranean streams. Environmental Management 45: 261-273. - doi: 10.1007/ s00267-009-9419-0

Loehle C, Van Deusen P, Wigley TB, Mitchell MS, Rutzmoser SH, Aggett J, Beebe JA, Smith ML (2006). A test of sustainable forestry guidelines using bird habitat models and the Habplan harvest scheduler. Forest Ecology and Management 232: 56-67. - doi: 10.1016/j.foreco.2006. 05.040

Nilsson SG, Niklasson M, Hedin J, Aronsson G, Gutowski JM, Linder P, Ljungberg H, Mikusinski G, Ranius T (2002). Densities of large living and dead trees in old-growth temperate and boreal forests. Forest Ecology and Management 161: 189-204. - doi: 10.1016/S0378-1127(01)00 480-7

Piotrowska M, Wesolowski T (1989). The breeding ecology and behaviour of the Chiffchaff Phylloscopus collybita in primaeval and managed stands of Bialowieza Forest (Poland). Acta Ornithologica 25: 25-76.

Piratelli A, Sousa SD, Corrêa JS, Andrade VA, Ribeiro RY, Avelar LH, Oliveira EF (2008). Searching for bioindicators of forest fragmentation: passerine birds in the Atlantic forest of southeastern Brazil. Brazilian Journal of Biology 68: 259-268. - doi: 10.1590/S1519-698420080
00200006

Przybyl K (2002). Fungi associated with necrotic apical parts of Fraxinus excelsior shoots. Forest Pathology 32: 387-394. - doi: 10.1046/j.14390329.2002.00301.x

R Development Core Team (2010). R: a language and environment for statistical computing. $\mathrm{R}$ Foundation for Statistical Computing. Vienna, Austria. [online] URL: http://www.r-project.org/ Roberge J-M, Angelstam P (2006). Indicator species among resident forest birds - a cross-regional evaluation in northern Europe. Biological Conservation 130: 134-147. - doi: 10.1016/j.biocon.2005.12.008

Roberge J-M, Angelstam P, Villard M-A (2008). Specialised woodpeckers and naturalness in hemiboreal forests - deriving quantitative targets for conservation planning. Biological Conservation 141: 997-1012. - doi: 10.1016/j.biocon.20 08.01.010

Rosenvald R, Lõhmus A, Kraut A, Remm L (2011). Bird communities in hemiboreal oldgrowth forests: the roles of food supply, stand structure, and site type. Forest Ecology and Management 262: 1541-1550. - doi: 10.1016/j.for eco.2011.07.002

Rowinski P (2001). Timing of breeding of Nuthatch Sitta europaea in relation to food resources in a natural forest. $\mathrm{PhD}$ thesis, SGGW, Warsaw, Poland, pp. 92. [in Polish]

Schlossberg S, King DI (2009). Postlogging succession and habitat usage of shrubland birds. Journal of Wildlife Management 73: 226-231. doi: $10.2193 / 2007-518$

Schowalter TD (1990). Invertebrate diversity in old-growth versus regenerating forest canopies. Northwest Environmental Journal 6: 403-404.

Schwenk WS, Donovan TM, Keeton WS, Nunery JS (2012). Carbon storage, timber production, and biodiversity: comparing ecosystem services with multi-criteria decision analysis. Ecological Applications 22: 1612-1627. - doi: 10.1890/110864.1

Shannon CE, Weaver W (1949). The mathematical theory of communication. University of Illinois Press, Urbana, IL, USA, pp. 117.

Spitzer L, Konvicka M, Benes J, Tropek R, Tuf IH, Tufova J (2008). Does closure of traditionally managed open woodlands threaten epigeic invertebrates? Effects of coppicing and high deer densities. Biological Conservation 141: 827-837. - doi: 10.1016/j.biocon.2008.01.005

Thompson ID, Hogan HA, Montevecchi WA (1999). Avian communities of mature balsam fir forests in Newfoundland: age-dependence and implications for timber harvesting. Condor 101: 311-323. - doi: 10.2307/1369994

Tomialojć L, Wesolowski T (1990). Bird communities of the primeval temperate forest of Bialowieza, Poland. In: "Biogeography and ecology of forest bird communities" (Keast A ed). SPB Academic Publ. Bv, The Hague, The Netherlands, pp. 141-165.

Tomialojć L, Wesolowski T (1994). Die Stabilität der Vogelmeinschaft in einem Urwald der gemässigten Zone: Ergebnisse einer 15 jährigen 
Studie aus dem Nationalpark von Bialowieza (Polen) [The stability of bird community in a temperate primaeval forest: 15-year data from the Białowieża National Park (Poland)]. Ornithologische Beobachter 91: 73-110. [in German]

Tomialojć L, Wesolowski T (1996). Structure of a primaeval forest bird community during 1970s and 1990s (Bialowieza National Park, Poland). Acta Ornithologica 31: 133-154.

Tomialojć L, Wesolowski T, Walankiewicz W (1984). Breeding bird community of a primaeval temperate forest (Bialowieza National Park, Poland). Acta Ornithologica 20: 241-310.

Toyoshima Y, Yamaura Y, Mitsuda Y, Yabuhara Y, Nakamura F (2013). Reconciling wood production with bird conservation: a regional analysis using bird distribution models and forestry scenarios in Tokachi district, northern Japan. Forest Ecology and Management 307: 54-62. doi: 10.1016/j.foreco.2013.07.006

Tozer DC, Burke DM, Nol E, Elliott KA (2010). Short-term effects of group-selection harvesting on breeding birds in a northern hardwood forest. Forest Ecology and Management 259: 15221529. - doi: 10.1016/j.foreco.2010.01.028

Verner J (1985). Assessment of counting techniques. Current Ornithology 2: 247-302. - doi: 10.1007/978-1-4613-2385-3 8

Walankiewicz W (2002). The number and compo sition of snags in the pine-spruce stands of the Bialowieza National Park, Poland. Gen. Tech. Rep. PSW-GTR 181, USDA Forest Service, Albany, CA, USA, pp. 489-500. [online] URL: http://wwwtest.fs.fed.us/psw/publications/documents/psw_gtr181/039_Walankiewicz.pdf

Walankiewicz W, Czeszczewik D, Mitrus C (2007). Natural nest sites of the Collared Flycatcher Ficedula albicollis in lime-hornbeam-oak stands of a primeval forest. Ornis Fennica 84 155-162. [online] URL: http://www.researchgate.net/publication/233863235

Walankiewicz W, Czeszczewik D, Mitrus C, Bida E (2002). Snag importance for woodpeckers in deciduous stands of the Bialowieza forest. Notatki Ornitologiczne 43: 61-71. [in Polish with English summary]

Walankiewicz W, Czeszczewik D, Stanski T, Sahel M, Ruczynski I (2014). Tree cavity resources in spruce-pine managed and protected stands of the Bialowieza Forest, Poland. Natural Areas
Journal 34: 500-505.

Walankiewicz W, Czeszczewik D, Tumiel T, Stanski T (2011). Woodpeckers abundance in the Bialowieza Forest - a comparison between deciduous, strictly protected and managed stands. Ornis Polonica 52: 161-168. [online] URL: http://dubelt.org.pl/wp-content/uploads/20 13/03/OP 20113 161-168.pdf

Wesolowski T (1995). Value of Bialowieza Forest for the conservation of white-backed woodpecker (Dendrocopos leucotos) in Poland. Biological Conservation 71: 69-75. - doi: 10.1016/ 0006-3207(94)00022-I

Wesolowski T (2005). Virtual conservation: how the European Union is turning a blind eye to its vanishing primeval forests. Conservation Biology 19: 1349-1358. - doi: 10.1111/j.1523-1739. 2005.00265.x

Wesolowski T (2011). "Lifespan” of woodpeckermade holes in a primeval temperate forest: a thirty year study. Forest Ecology and Management 262: 1846-1852. - doi: 10.1016/j.foreco.20 11.08 .001

Wesolowski T (2012). "Lifespan" of non-excavated holes in a primeval temperate forest: a 30 year study. Biological Conservation 153: 118126. - doi: 10.1016/j.biocon.2012.04.017

Wesolowski T, Czeszczewik D, Rowinski P (2005). Effects of forest management on Threetoed Woodpecker Picoides tridactylus distribution in the Bialowieza Forest (NE Poland): conservation implications. Acta Ornithologica 40: 53-60. - doi: 10.3161/068.040.0111

Wesolowski T, Mitrus C, Czeszczewik D, Rowinski $P$ (2010). Breeding bird dynamics in a primeval temperate forest over 35 years: variation and stability in a changing world. Acta Ornithologica 45: 209-232. - doi: 10.3161/000164510X 551354

Wesolowski T, Rowinski P (2006). Tree defoliation by winter moth Operophtera brumata L. during an outbreak affected by structure of forest landscape. Forest Ecology and Management 221: 299-305. - doi: 10.1016/j.foreco.2005.10.023

Wesolowski T, Rowinski P, Mitrus C, Czeszczewik D (2006). Breeding bird community of a primeval temperate forest (Bialowieza National Park, Poland) at the beginning of the $21^{\text {st }}$ century. Acta Ornithologica 41: 55-70. - doi: 10.31 61/068.041.0112

Wesolowski T, Tomialojć L, Mitrus C, Rowinski
P, Czeszczewik D (2002). The breeding bird community of a primaeval temperate forest (Bialowieza National Park, Poland) at the end of the $20^{\text {th }}$ century. Acta Ornithologica 37: 27-45. doi: 10.3161/068.037.0105

Zhang J-T, Wang C (2012). Biodiversity and ecosystem functioning: exploring large-scale patterns in mainland China. iForest 5: 230-234. doi: 10.3832/ifor0627-005

\section{Supplementary Material}

\section{Appendix 1}

Tab. S1 - Bird community (abundance index) in spruce-pine natural stands (SP-NAT) in 2010-2012.

Tab. S2 - Bird community (abundance index) in spruce-pine semi-natural stands (SPSEMI) in 2010-2012.

Tab. S3 - Bird community (abundance index) in spruce-pine managed stands (SPMAN) in 2010-2012.

Tab. S4 - Bird community (abundance index) in lime-hornbeam natural stands (LHNAT) in 2010-2012.

Tab. S5 - Bird community (abundance index) in lime-hornbeam semi-natural stands (LH-SEMI) in 2010-2012.

Tab. S6 - Bird community (abundance index) in lime-hornbeam managed stands ( $\mathrm{LH}-$ MAN) in 2010-2012.

Tab. S7 - Bird community (abundance index) in ash-alder natural stands (AA-NAT) in 2010-2012.

Tab. S8 - Bird community (abundance index) in ash-alder semi-natural stands (AASEMI) in 2010-2012.

Tab. S9 - Bird community (abundance index) in ash-alder managed stands (AAMAN) in 2010-2012.

Link: Czeszczewik_1212@suppl001.pdf 